\title{
IN WHICH REGIONS DO UNIVERSITIES PATENT AND PUBLISH MORE?
}

\author{
J. M. Azagra-Caro ${ }^{(p)}$, F. Archontakis, A. Yegros-Yegros
}

\begin{abstract}
The main objective of this contribution is to test whether university patents share common determinants with university publications at regional level. We build some university production functions with 1,519 patents and 180,239 publications for the 17 Spanish autonomous regions (NUTS-2) in a time span of 14 years (1988-2001). We use some econometric models to estimate their determinants. Our results suggest that there is little scope for regional policy to compensate the production of patents vs. publications through different university or joint research institutional settings. On the contrary, while patents are more reactive to expenditure on R\&D, publications are more responsive to the number of researchers, so the sustained promotion of both will make it compatible for regions their joint production. However, standing out in the generation of both outputs requires costly investment in various inputs.
\end{abstract}

Keywords: University patents, university publications, scientific production, regions

\section{Resumen}

El principal objetivo de esta contribución es comprobar si las patentes universitarias comparten determinantes con las publicaciones universitarias a nivel regional. Se ha generado unas funciones de producción con 1,519 patentes y 180,239 publicaciones para las 17 comunidades autónomas españolas, contemplando un periodo temporal de 14 años (1988-2001). Se ha utilizado algunos modelos econométricos para estimar sus determinantes. Los resultados obtenidos sugieren que la política regional posee un alcance limitado para compensar la producción de patentes con la de publicaciones a través de diferentes contextos universitarios o de centros mixtos. Por el contrario, mientras que las patentes se muestran más reactivas a los gastos de I+D, las publicaciones parecen ser más sensibles al número de investigadores, por lo que la promoción sostenida de ambos recursos hará compatible la producción conjunta de patentes y publicaciones. A su vez, esto implica que destacar en la generación de ambos tipos de resultado requiere costosas inversiones en diversos recursos

Palabras clave: Patentes universitarias, publicaciones universitarias, producción científica, regiones

\section{Introduction}

The rise of university patents has been a common trend for most developed countries during the last thirty years ${ }^{1}$. Some theoretical approaches to the relation between university science

\footnotetext{
${ }^{1}$ We will use this term to refer to patents applied for by universities. On patents with university inventors applied for by other institutions, see Meyer-Krahmer and Schmoch [34], Meyer [32], Calderini et al. [11] and Azagra et al. [4].
} 
and industrial innovation provide some grounds to support these views. For Clark ([15]: p. 7), "entrepreneurial universities learn faster than non-entrepreneurial counterparts that money from many sources enhances the opportunity to make significant moves without waiting for systemwide enactments that come slowly, with standardizing rules attached". For supporters of the Triple Helix approach, enhanced efforts by universities to be commercially relevant are a natural outcome of the changing role that society requires from them, more aimed at providing direct contributions to economic development (Etzkowitz and Leydesdorff, [23]).

Other voices have been more critical. Feller [24] foresaw an "erosion of the singular position of universities in US", whose traditional independence of market incentives committed them to an efficient supply of scientific and technological knowledge. Moreover, he found "little reason to expect that a substantial reallocation of faculty effort will generate appreciable net revenues for other than a select number of universities". The economics of science approach (Dasgupta and David [20]) theoretically justified these views by pointing to the substitutive effects between R\&D leading to patents, and other research which provides less tangible but wider benefits.

These conflicting views make university patents a relevant topic for policy making. Our main interest is to focus the debates in a regional context. The region is a crucial unit of observation for its capacity to implement science and technology policies and embed an idiosyncratic culture (Cooke [16]). Hence, an immediate question is: do we confirm the common empirical findings on university patents of studies at sub-regional level when we analyse the regional level, e.g. regarding their relation to R\&D expenditure?

Besides, the use of regions may provide useful insights into other issues. For instance, we may wonder whether it would make sense for regions to choose strategically among different university and joint research structures to increase the number of university patents. Overall, our target question is: do regions have any scope to influence the generation of university patents through their academic structure?

Moreover, the Triple Helix approach defends that the differences between basic and applied research are eventually blurring in growing fields of science with spontaneous industrial application. Therefore, it is natural that most productive faculty generate their traditional output, publications, but also patents (Etzkowitz [22]). This view takes distance from the concern that university patents are not a relevant contribution to innovation, since the efforts to conduct research leading to patents may distort the resources devoted to other more useful research (Pavitt [40]). In particular, we wonder where there might be a trade-off between R\&D or other inputs leading to patents and publications. A constructive balance of inputs leading to both outputs may be important for a well working regional innovation system. Summing up: do the same forces drive university patents and publications?

The rest of this paper follows the traditional structure to find some answers. Section 2 presents the literature review. Section 3 describes the methodology and the data used to expand our knowledge. Section 4 gives the results. Section 5 reaches some conclusions.

\section{Literature review}

\subsection{University patents and research productivity}

\subsubsection{What is their relation at sub-regional level?}

Several studies apply econometric techniques to estimate the relation between university patents and different explanatory variables. The first six (Foltz et al. [26]; [27]; Carlsson and Fridh [13]; Payne and Siow [41]; Coupé [17]; Baldini et al. [6]) use universities as a unit of 
observation, five in the US case and one in the Italian case. Two of them refer to the department or laboratory level of single European universities (Azagra et al. [3], [4]). A final study uses individuals as the unit of observation, from two MIT departments (Agrawal and Henderson [2] $)^{2}$.

The most frequent determinant included is R\&D expenditure. Carlsson and Fridh [13] find a significant positive impact of aggregate R\&D on the number of disclosures. Payne and Siow [41] and Coupé [17] conclude that the returns of federally funded R\&D to patents are decreasing. Foltz et al. [26] find the sum of federal and state funding positive and significant for all university patents but not significant for agricultural biotechnology university patents. Foltz et al. [27] find that state funding has a positive, significant, influence on agricultural biotechnology university patents while federal funding has not. Azagra et al. [3] find more costly, long-term-oriented, public funds significant, but not less costly, short-term-oriented ones. Azagra et al. [4] find regional public funds significant. Hence, it seems reasonable to propose the following hypothesis:

Hypothesis 1. The higher the amount of university R\&D funds, the more likely it is that universities will generate patents.

A second usual determinant of university patents is size. Foltz et al. [27] and Payne and Siow [41] do not find the number of faculty significant but Coupé [17] does. Azagra et al. [3] do not find it significant but Azagra et al. [4] do. Baldini et al. [6] do not always find significant the effect of budget transfer from central government, taken as a proxy for size rather than for R\&D resources. Overall, the evidence is not conclusive. We will state the following hypothesis with the expectation of a positive sign:

Hypothesis 2. The higher the number of university researchers, the more likely it is that universities will generate patents.

Other determinants are external forces that grow as time goes by. ${ }^{3} \mathrm{~A}$ trend variable may capture them. Coupé [17], Azagra et al. [3] and Baldini et al. [6] find this trend positive and significant but Azagra et al. [4] do not. The explanation may be in the national features of the following forces:

- Strength of technology transfer offices (TTO): Foltz et al. [26] find that the number of employees of the TTO matters positively and significantly. In turn, Foltz et al. [27] find that this measure is not significant, while a measure of the quality of the TTO is positive and significant. Coupé [17] includes a dummy variable indicating the year of establishment of the TTO at the university, finding a positive and significant influence. The same happens to Carlsson and Fridh [13] with the number of disclosures, on which the number of patent applications depends. They also find the influence of the number of TTO employees significant and positive. Azagra et al. [3] find this too.

- University R\&D spillovers: Coupé [17] includes a measure of aggregate R\&D of other universities and he finds its impact positive and significant. Azagra et al. [3] reach the same result.

\footnotetext{
${ }^{2}$ We should also mention other studies where the dependent variable is not patents but something related. Thursby and Kemp [45] explain whether universities are efficient or not for commercial activities, patenting included. Siegel et al. [43] analyse productivity of TTO, measured through the number of licenses and their revenue. Bercovitz and Feldman [7] study the determinants of having filed a disclosure between 1997 and 1999.

${ }^{3}$ This is not to say that there are no more internal determinants of university patenting. Foltz et al [27] and Coupé [17] include a measure of faculty quality (average wage). Foltz et al. [27] and Baldini et al. [6] include a measure of patenting experience.
} 
- Legal framework: Coupé [17] uses a dummy variable to measure the legal change represented by the Bayh-Dole Act, without a significant effect. Something similar occurs to Azagra et al. [3] with a dummy for an internal legal change that took place in their case study. However, Baldini et al. [6] find that the adoption of an internal regulation is significant.

Consequently, this is the hypothesis we want to test:

Hypothesis 3. Over time, external forces (e.g. strength of TTO, university R\&D spillovers, legal framework) make the number of university patents increase.

\subsubsection{Do regions have any scope to influence the generation of university patents through their academic structure?}

One may distinguish among types of universities according to the historical period of their creation, since each period may foster different missions and organisational structures, e.g. medieval, contemporary and post-World War II universities (Geuna [28]). One may think of different technical orientations (polytechnics and other) or regimes of ownership (public or private), etc.

These differences may be relevant for the production of university patents. Coupé [17] makes a distinction between public and private universities but he does not find significant differences. Foltz et al. [26] find that the presence of agricultural schools and the importance of agriculture in the local economy help to explain the production of agricultural biotechnology university patents. Baldini et al. [6] do not find evidence that the presence of a medical school affects patenting. In addition, Mowery and Sampat [35] show that, according to the prevailing incentives at a particular time, public or private universities will change their interest in patenting. In any case, regions may contain different numbers and types of universities, because of their own historical trajectory and decision-making. This motivates the following hypothesis:

Hypothesis 4. University structure matters: the composition of universities according to their age, technical orientation or regime of ownership will influence the generation of patents.

The existence of joint research centres between universities and public research organisations (e.g. CNRS in France, CNR in Italy, CSIC in Spain) implies access to larger capital and human infrastructure in order to obtain newer and more important discoveries. Hence, for universities, having joint research centres with public organisations may increase their resources. Besides, these organisations may have cultural and functional features that lead to higher protection by means of patents, e.g. their preference for research leading to practical applications as compared to universities (Cesaroni and Piccalugga [14]) or the lack of teaching responsibilities. Azagra et al. [3] show that the presence of a joint research centre at a university increases its propensity to patent. For these reasons, we present the following hypothesis:

Hypothesis 5. Joint research structure matters: the higher the number of joint research centres between universities and other public research organisations, the more likely it will be that universities generate patents.

\subsection{University patents and university publications: do the same inputs produce both outputs?}

The literature has long studied the idea that certain personal characteristics matter in the process of scientific production, e.g. age or gender (Stephan [44]; Xie and Shauman [47]). The analysis at institutional level is most recent but it is enough to show some evidence that 
there exists a relation between university R\&D and university publications (Adams and Griliches [1]; Crespi and Geuna [19]). At laboratory level, the negative effects of age structure and size and the inconclusive effect of spatial agglomeration have also been tested (Bonaccorsi and Daraio [8], [9]).

The explained variable has always been the count of publications, sometimes weighted by the number of citations. The analysis of university patents have been the focus of studies like those in section 2.1.1. However, both traditions think in terms of common determinants, e.g. R\&D or size. Payne and Siow [41] actually explain university publications and patents as a function of these. They find that each additional one million dollars in federal funding produces 11 articles and 0.2 patents. Size, measured through number of faculty, does not have a significant impact on any outputs.

Another econometric approach to the relation between university publications and patents has been to estimate the former as a function of the latter, and/or vice versa, at individual or laboratory level. Thus, Agrawal and Henderson [2] show that the number of papers (patents) does not depend on the number of current and lagged patents (papers) ${ }^{4}$. In turn, Carayol and Matt [12] regress average publication performance on number of patent applications and find a positive relation. In any case, this approach are arguable, it shows no negative association between university publications and patents. Breschi et al. [10] overcome arguable assumptions on the direction of causality by using a hazard function, and they find a positive relation. ${ }^{5}$

No attempts have been made to study this issue at regional level. On the former basis, we start by formulating an intuitive hypothesis:

Hypothesis 6. The determinants of university patents and university publications are coincident.

\section{Methodology and data}

The aim of the present section is to estimate some econometric models on the determinants of university patents and publications and test the hypotheses raised.

The sample contains data about Spain, a member country of the European Union (EU). According to OECD [37], Gross Expenditure on Research and Development (GERD) as a percentage of GDP grew from 0.41 in 1981 to 0.97 in 2001, the first year to reach $50 \%$ of the EU average. GERD performed by the Business Enterprise sector rose from $45.5 \%$ to $54.3 \%$ in the same period, around 0.2 times lower than the EU average in the last decade. In turn, GERD performed by the Higher Education sector rose from $22.9 \%$ to $29.4 \%$ and was around 0.4 times higher than the EU average. However, Higher Education Expenditure on Research and Development (HERD) as a percentage of GDP, which augmented from 0.09 to 0.28 , has only reached $70 \%$ of the EU average in 2000 . Hence, Spanish universities perform more R\&D activities than Spanish firms do in relative terms, but still little compared to EU universities. This is representative of peripheral countries of the EU as well as of economically developed countries with some technological weaknesses. Nevertheless, HERD financed by industry has increased from $1.2 \%$ in 1984 to $6.9 \%$ in 2000 , fluctuating widely above the EU average from 1988, maybe due to statistical reasons $(17 \%$ more in 2000). In any case, it seems that Spanish universities follow the general trend of increased industrial funding, common to most Western economies.

\footnotetext{
${ }_{5}^{4}$ However, they find some complementarities between patenting impact and publishing impact.

${ }^{5}$ Biliometrics also suggest a positive association between publishing and patenting, at least in a science-based technology (Meyer, [33]).
} 
We collected data for 14 years and the 17 Spanish autonomous regions. The resulting database is therefore a 238 -observation panel. ${ }^{6}$

\subsection{Dependent variables and methods of estimation}

A first set of data comprise Spanish university patents in the period 1988-2001. We include applications and grants, because both sorts of documents integrate the state of the art and can be a reference for future patents. Data come from the CIBEPAT database of the Spanish Patent and Trademark Office (OEPM).

Our period of observation begins from 1988 because data for some independent variables start in 1987 and we assume, at least, a one year lag with them (see next sub-section). It is a good starting date in that the European Patent Agreement came into force in Spain in 1986 and the PCT in 1989. The last year of the sample is 2001 because of the delay of updating.

We made a query to identify all patents with at least one Spanish university among the applicants. As we may see in Table 1, we found 1,479 "real" patents. We assigned patents to regions according to the main site of the university. When more than one university appeared in the list of applicants, we chose to assign one patent per university. This way, we generated 1,519 "counted" patents. Therefore, this method does not produce a high distortion in the data, only $2.7 \%$. Another reading of this is that there is little collaboration between Spanish universities to get protection for technological discoveries.

Table 1 also shows that most patent documents are national patents (94.5\% of real and counted patents) while international patents represent a low percentage (5.5\% of real and counted patents) of all the patents maybe because of their higher costs and requirements.

In addition, while most national patents are grants $(81.6 \%)$, most international patents are applications $(75.9 \%)$ due to the delay of the granting process.

\begin{tabular}{lcccc}
\hline & Real patents & \multicolumn{3}{c}{ Counted patents } \\
\cline { 2 - 5 } & Total & Applied patents & Granted Patents & Total \\
\hline National patents & 1398 & 264 & 1172 & 1436 \\
\hline International patents & 81 & 63 & 20 & 83 \\
\hline European patents & 10 & 7 & 3 & 10 \\
\hline PCT patents & 71 & 56 & 17 & 73 \\
\hline TOTAL & 1479 & 327 & 1192 & 1519 \\
\hline
\end{tabular}

Table 1. Distribution of real and counted patents by route of patenting

Source: OEPM: Cibepat and own elaboration.

Considering all this, we defined the next variables for the estimations:

- Natpat: number of Spanish university counted patents applied for through the national route.

- Natgrant: number of Spanish university counted patents granted through the national route.

${ }^{6}$ There have been some studies on university patents in Spain, not published in English. They tend to assume that university patents are positive and the main question is how to enhance their generation. (Fernández de Córdoba, [25]; Durán, [21]; Coronado et al., [18]). 
- Intpat: number of Spanish university counted patents applied for through an international route, i.e. the sum of both European and PCT patents. We considered it appropriate to add together these two sets of patents because of the small number of patents in each one.

Our framework of analysis is the knowledge production function introduced by Griliches [30]. In order to find the adequate estimation technique, we must take into account that patents are typical count data. The baseline model is the Poisson regression model (PRM), which holds under the assumption of equidispersion. An extension of the PRM is the Negative Binomial Regression Model (NBRM), which relaxes this assumption. However, one might argue that different reasons cause the presence of zeros. Zero-inflated count models respond to this failure.

Because of the small number of international patents, we followed an alternative approach by creating the following variable:

- Intpat2: having at least one university counted patent, applied for through an international route. It is a transformation of intpat, leaving data with zeros as they were originally and transforming all the rest into ones.

Following this alternative approach, a more appropriate technique of estimation for intpat2 is the Probit Model.

A second set of data comprise Spanish university publications, namely, those included in the Web of Science databases of Thomson Scientific-ISI during the period 1988-2001. Arts and Humanities Citation Index, Science Citation Index and Social Sciences Citation index are multidisciplinary databases that cover mainstream international scientific journals.

In order to search for the Spanish university publications, all records including a Spanish university in the address field were retrieved. Moreover, the query included the variants corresponding to each Spanish university's name to ensure the exhaustiveness in the retrieving process.

Whole counting scheme is used, that is to say, each "real" publication out of 159,015 has been assigned in full to all unique institution appearing in the address field (Okubo [38]). A consequence of this counting method is the larger number of "counted" publications, 180,239 in total, due to the collaboration between Spanish universities. The rate of duplication is therefore $13.3 \%$, higher than in the case of patents, which means that scientific collaboration is a more frequent practice than technological cooperation among universities.

All types of documents were taken into account (articles, reviews, editorials, letters, etc.). Finally, we use this variable:

- Lpub: logarithm of the number of Spanish university counted international publications in the $\mathrm{AHCl}, \mathrm{SCl}$ and $\mathrm{SSCl}$ databases.

We employed models for panel data to do the estimations.

\subsection{Independent variables and selection technique}

All the independent variables in the regression model are lagged one year in order to prevent endogeneity as much as possible. A first set of data comes from the National Statistics Institute (INE), specifically from R\&D activities statistics. Regionalisation of these data started in 1987, which explains the beginning of our period of observation:

- Lherd: logarithm of the real value of university R\&D expenditure (in thousand Euro), using the GDP deflator. 
- Lfte: logarithm of the number of Full Time Equivalent (FTE) researchers.

- We also introduce the following variable:

- Trend: year of the patent application.

Aspects concerning university structure come from the Universia.es portal ${ }^{7}$ :

- Univst1: a vector of three variables classifying universities according to their regime of ownership and being a polytechnic. Ppub is the proportion of public, non-polytechnic universities, $p p o l$ the proportion of public, polytechnic universities and ppriv the proportion of private universities. We use ppub as the benchmark.

- Univst2: a vector of four variables classifying universities according to epoch of creation, following Geuna [28] and Rodríguez-San Pedro [42]: pmed is the proportion of medieval universities (up to 1475), pmod of modern universities (up to 1800), pcont of contemporary universities (up to 1943) and prec of recent universities. Pmed is the benchmark.

Since univst1 and univst2 overlap, we use them alternatively for the estimations.

From the Spanish High Council for Scientific Research's (CSIC) reports, we build the variables regarding other public research infrastructure:

- Pjoi: ratio of number of university-CSIC joint research centres to number of universities.

Although not to test any hypothesis, it is important to control for regional capacity and thus we built the following variable from INE:

- Lpop: logarithm of population size.

Table 2 shows descriptive statistics of the independent variables. The average R\&D expenditure was 34.3 million euros per region and year while the average number of FTEresearchers was 1385 . There were around three universities per region and year: more than $84 \%$ were public, around $12 \%$ were private and less than $4 \%$ were polytechnics. According to their time of creation, there were $3 \%$ medieval, $19 \%$ modern, $15 \%$ contemporary and $63 \%$ recent universities. For joint research centres there were more than one per region and year while their proportion was approximately $37 \%$, i.e. more than one third of universities had one joint research centre on average. Finally, the average region had a population of 2.3 million people.

When we run the regressions, we follow this selection strategy: we start by choosing between Poisson, negative binomial and zero inflated models. Once the best technique has been selected, we delete the non-significant variable the coefficient of which has the worst tvalue $^{8}$. We estimate a reduced model without the deleted variable. We make a likelihood ratio test against the original model. If the test shows preference for the reduced model, we repeat the previous steps. If there are no non-significant variables to delete, we accept the reduced model ${ }^{9}$.

\footnotetext{
${ }^{7}$ http://www.universia.es.

${ }^{8}$ In the case of groups of dummies (univst1, univst2), we test their joint significance.

${ }^{9}$ In a similar fashion we carried out the selection procedure for the probit and panel data models.
} 
Azagra et al. / X International Congress on Project Engineering

\begin{tabular}{lllllll}
\hline Variable & Mean & Std.Dev. & Skewness & Kurtosis & Minimum & Maximum \\
\hline Herd & 34341.6 & 39254 & 1.57601 & 4.45536 & 0 & 157684 \\
\hline Fte & 1385.13 & 1615.24 & 1.75914 & 5.48994 & 0 & 7802 \\
\hline Ppub & 0.845971 & 0.214805 & -0.959798 & 2.39631 & 0.333333 & 1 \\
\hline Ppol & 0.0346885 & 0.0812606 & 2.41663 & 7.87373 & 0 & 0.333333 \\
\hline Ppriv & 0.119341 & 0.19732 & 1.31779 & 3.14932 & 0 & 0.666667 \\
\hline Pmed & 0.033691 & 0.106962 & 3.39215 & 13.6024 & 0 & 0.5 \\
\hline Pmod & 0.185578 & 0.333386 & 1.78634 & 4.67427 & 0 & 1 \\
\hline Pcont & 0.153797 & 0.255156 & 1.7164 & 5.37017 & 0 & 1 \\
\hline Prec & 0.626934 & 0.346687 & -0.658058 & 2.24702 & 0 & 1 \\
\hline Pjoi & 0.367389 & 0.547863 & 1.95464 & 7.62337 & 0 & 3 \\
\hline Pop & 2329184.71 & 2005968.62 & 1.16923 & 3.1667 & 260964 & 7340052 \\
\hline
\end{tabular}

Table 2. Descriptive Statistics of independent variables ${ }^{10} . \mathrm{N}=238$.

\section{Results}

We show the final reduced models in Table 3. For count data models negative binomial estimations were always preferred to Poisson and zero inflated negative binomial ones. For the OLS estimation, a fixed effects model with regional dummies was preferred to a random effects model and to the inclusion of time dummies.

We start with Columns 1 to 4 , referred to patents. There is empirical evidence that Hypothesis 1 is valid, since the variable of R\&D expenditure indicates a significant positive relation with the number of university patents in all estimations. From columns 1 to 3 , we see that a one percent increase in R\&D funds will increase the number of patents issued by universities more than $2 \%$ and the number of international patents by $6 \%$. Via a Wald test, at $5 \%$ significance level we reject the hypothesis that the estimated coefficients of R\&D for national and international patents are equal.

Moreover, this is a higher ratio than in previous results by Payne and Siow [41] and Coupé [17], where the increase of patents was not higher than $1 \%$. The explanation may lie in the fact that they use only public funding rather than all funding. However, Azagra et al. ([3], [4]) also use all funding but find lower elasticity for R\&D funds. A second explanation may be, then, the unit of observation. Adams and Griliches [1] find that research output follows diminishing returns to scale at the individual level but constant returns at the aggregate level. We treat our sample data at an even higher level of aggregation.

The data do not confirm Hypothesis 2, so the number of university researchers does not seem to influence the number of patents issued in Spain.

The data give evidence to support Hypothesis 3 only in the case of natpat. We find the time trend significant, as in Azagra et al. ([3], [4]) and Coupé [17], meaning that there are exogenous factors not included in the present model, which produce only more national applications, i.e. probably lower quality patents. Henderson et al. [31] and Mowery and

${ }^{10}$ Note that for the estimations we took non-proportion variables (herd, fte, pop) in logs (Iherd, Ifte, Ipop). 
Ziedonis [36] find somewhat similar results in the US case, regarding the declining quality of university patents.

\begin{tabular}{|c|c|c|c|c|c|}
\hline & $\begin{array}{l}1 \\
\text { Negative } \\
\text { Binomial } \\
\text { Regression }\end{array}$ & $\begin{array}{l}2 \\
\text { Negative } \\
\text { Binomial } \\
\text { Regression }\end{array}$ & $\begin{array}{l}3 \\
\text { Negative } \\
\text { Binomial } \\
\text { Regression }\end{array}$ & $\begin{array}{l}4 \\
\text { Binomial } \\
\text { Probit Model }\end{array}$ & $\begin{array}{l}\mathbf{5} \\
\text { Least } \\
\text { Squares } \\
\text { with Group } \\
\text { Dummy } \\
\text { Variables }\end{array}$ \\
\hline $\begin{array}{l}\text { Dependent } \\
\text { variable }\end{array}$ & Natpat & Natgrant & Intpat & Intpat2 & Lpub \\
\hline $\begin{array}{l}\text { Number of } \\
\text { observations }\end{array}$ & 238 & 238 & 238 & 238 & 238 \\
\hline $\begin{array}{l}\text { Log likelihood } \\
\text { function }\end{array}$ & -509.28 & -508.17 & -133.18 & -79.99 & 222.00 \\
\hline $\operatorname{Prob}\left[x^{2}>\right.$ value $]$ & 0.00 & 0.00 & 0.00 & 0.00 & 0.00 \\
\hline \multirow[t]{2}{*}{$\mathrm{R}^{2}$} & 0.84 & 0.76 & 0.52 & 0.84 & 0.97 \\
\hline & Coeff. (t-tatio) & Coeff. (t-tatio) & Coeff. (t-tatio) & Coeff. (t-tatio) & Coeff. (t-tatio) \\
\hline Constant & $-179.25(-6.07)$ & $-9.24(-13.75)$ & $-5.89(-1.38)$ & $-1.35(-0.51)$ & \\
\hline Lherd & $2.33(17.02)$ & $2.38(16)$ & $6.01(4.52)$ & $3.66(4.52)$ & \\
\hline Lfte & & & & & $0.16(8)$ \\
\hline Trend & $0.09(5.75)$ & & & & $0.04(16.72)$ \\
\hline Ppol & $1.11(1.79)$ & & $0.02(0.01)$ & $1.1(0.78)$ & $-0.15(-0.95)$ \\
\hline Ppriv & $-0.57(-2.1)$ & & $-2.39(-2.31)$ & $-1.76(-2.5)$ & $-0.25(-2.52)$ \\
\hline Lpop & & & $-3.51(-2.44)$ & $-2.49(-2.82)$ & \\
\hline$\alpha$ & $0.27(4.66)$ & $0.58(5.96)$ & $1.32(2.65)$ & & \\
\hline
\end{tabular}

Table 3. Estimation of Spanish university patent and publication production functions

T-ratios in parenthesis. $R^{2}$ is the Poisson-associated model $R^{2}$ for the Negative Binomial Regression and the count $\mathrm{R}^{2}$ for the Binomial Probit Model

The data partially support Hypothesis 4, i.e. university structure influences the production of national university patents. Age structure (univst2) is never jointly significant. Other characteristics (univst1) are sometimes significant. A higher proportion of polytechnic universities will involve a (weak) increase of national applications, but not of any other kind of patents. A higher proportion of private universities will lead the region to apply less often for every kind of patents.

The data do not support Hypothesis 5 - joint research structure does not influence the production of university patents. ${ }^{11}$

If we now look into Column 5 , referred to university publications, we can see that there is conflicting evidence to support Hypothesis 6 . We would reject it because R\&D should have a significant effect on publications as on patents, but it does not, and because the opposite occurs with the number of researchers. We would accept the hypothesis because university structure and the trend are influential, pointing in the same direction as the effect on patents: over time, the number of publications increases, whereas a higher proportion of private universities will make it decrease. Moreover, the proportion of joint research centers has no significant effect, as on patents. In any case, what comes out of the analysis is that there are

\footnotetext{
${ }^{11}$ We tried to discount joint centres in social sciences and humanities from our measure. It did not change the results.
} 
no inputs with significant effects and different signs on publications and patents, so it is compatible for regions to produce both.

\section{Conclusions}

Three main interests guided this research: Do we confirm the relation between university patents and research productivity at regional level? If so, do regions have any scope to influence the generation of university patents through their academic structure? In addition, do the same forces drive university patents and publications?

According to our results, university patents are an expression of R\&D efforts also when we focus on the region, and patent applications are an indicator of how regions organize their university structure. Therefore, if there is a re-composition of academic R\&D favouring patentable results, regions can control their university structure to compensate for it, e.g. hindering the proportion of polytechnic universities and favouring the proportion of private universities $^{12}$.

However, the former will have no effect on university publications while the latter will also decrease the probability of generating these publications. Besides, no option guarantees some bearing on national patent grants. Consequently, the scope of changes in university structure is very limited. In Spain, the reason may be that regional governments have created recent universities in order to attend for increases in population and students after economic buoyancy, rather than as a deliberate attempt to improve local scientific and technological production.

In the same sense, we are concerned with the non-confirmation that a stronger presence of joint research centres may increase the probability of generating patents and publications at universities. If our results are certain, a possible explanation may lie in a too high proportion of university professors in their staff and a too low share of CSIC researchers, with the consequent heavy teaching load. We recall that joint research centres may be still useful to produce other benefits at regional level, e.g. scientific networks, contracts, spin-off firms, etc.

More possibilities arise if we think that while university patents are more reactive to expenditure on R\&D at regional level, university publications are more responsive to the number of researchers, i.e. financial capital is more important for the former, human capital for the latter. It means that sustained promotion of both will make it compatible for regions their joint production.

It also implies that standing out in the generation of both outputs requires costly investment in many inputs. The sacrifice is relevant for an efficient working of a regional innovation system, since universities may be able to interact with several types of local firms -those interested in direct technological potentialities, mainly embedded in patents, and those able to absorb broader scientific knowledge with riskier but more creative application, mainly related to publications.

We must mention some limitations in our econometric models. We prevented endogeneity to some extent by lagging all the independent variables one period, but the problem may still exist if older patents are an input for some of them. We could reduce it by trying with longer lags, but then we would lose some observations. In addition, we did not test for spatial autocorrelation. However, the negative binomial and zero inflated models that we use take

\footnotetext{
12 In a related article we found that if we included variables to measure the motivation to catch-up with the technological competencies of other institutions in the region, the university structure effect loses its significance (Azagra et al., [5]). We interpret it as a sign that this motivation to catch-up is specially present at polytechnics, whereas it is scarce in private universities.
} 
into account heterogeneity among regions, so this and the inclusion of population size as a determinant should reduce the problem.

\section{References}

[1] Adams, J. D., Z. Griliches, 2000. Research Productivity in a System of Universities. Encaoua D., B. H Hall., F. Laisney, J. Mairesse (eds.): The Economics and Econometrics of Innovation. Dordrecht: Kluwer Academic Publishers.

[2] Agrawal, A., R. Henderson, 2002. Putting Patents in Context: Exploring Knowledge Transfer from MIT. Management Science 48 (1): 44-60.

[3] Azagra-Caro, J., I. Fernández-de-Lucio, A. Gutiérrez-Gracia, 2003. University patents: output and input indicators... of what? Research Evaluation 12 (1): 5-16.

[4] Azagra-Caro, J., N. Carayol, P. Llerena, 2006a. Patent Production at a European Research University: Exploratory Evidence at the Laboratory Level. Journal of Technology Transfer 31 (3), forthcoming.

[5] Azagra-Caro, J., A. Yegros-Yegros, F. Archontakis, 2006b. What do university patent routes indicate at regional level?, Scientometrics 66 (1), forthcoming.

[6] Baldini, N., R. Grimaldi, M. Sobrero, 2004. Institutional changes and the commercialization of academic knowledge: a study of Italian universities patenting activities between 1965 and 2002, CRESCO Working Paper 11.

[7] Bercovitz, J., M. Feldman, 2003. Technology transfer and the academic department: who participates and why? DRUID Summer 2003 Conference, Copenhagen (Denmark), June 12-14.

[8] Bonaccorsi, A., Daraio, C., 2003. Age effects in scientific productivity: The case of the Italian National Research Council (CNR). Scientometrics 58 (1): 49-90.

[9] Bonaccorsi, A., Daraio, C., 2005. Exploring size and agglomeration effects on public research productivity. Scientometrics 63 (1): 87-120.

[10] Breschi, S., Lissoni, F., Montobbio, F. (2005). From publishing to patenting. Do productive scientists turn into academic inventors? Revue d'Économie Industrielle 110: 75102.

[11] Calderini, M., C. Franzoni, A. Vezzulli, 2004. Scientific Eminence, Quality of Research and the Decision to Patent in Academic Career. An Event History Analysis. Conference on Innovation, Entrepreneurship and Growth, Royal Institute of Technology Studies, Stockholm, 18-20 November.

[12] Carayol, N., Matt, M., 2004. Does research organization influence academic production? Laboratory evidence from a large European university. Research Policy 33: 1081-1102.

[13] Carlsson, B., A. C. Fridh, 2002. Technology Transfer in the United States Universities. Journal of Evolutionary Economics 12, 199-232.

[14] Cesaroni, F., Piccaluga, A., 2002. Patenting activities of European Universities. Relevant? Growing? Useful? SPRU NPRnet Conference Rethinking Science Policy. Brighton (UK), 21-23 March.

[15] Clark, B. R., 1998. Creating Entrepreneurial Universities. Guilford: IUA Press, Pergamon. 
[16] Cooke, P., 1992. Regional Innovation Systems: Competitive Regulation in New Europe. Geoforum 23 (3): 365-382.

[17] Coupé, T., 2003. Science is Golden: Academic R\&D and University Patents. Journal of Technology Transfer 28, 31-46.

[18] Coronado Guerrero, D., M. Acosta Seró, R. Marín Muñoz, 2003. La contribución de la universidad al desarrollo de la tecnología industrial. Diferencias sectoriales, regionales y factores determinantes. XXIX Reunión de estudios regionales, Santander, 27-28 de noviembre.

[19] Crespi, G., Geuna, A., 2005. Modelling and Measuring Scientific Production: Results for a Panel of OECD Countries. SPRU Electronic Working Paper Series, Paper No. 133.

[20] Dasgupta, P., P. David, 1994. Towards a new economics of science. Research Policy 23 (5): 487-521.

[21] Durán Romero, G., dir., 2003. Análisis y comparación de las patentes universitarias españolas como indicador de resultados del esfuerzo investigador. Madrid: Ministerio de Educación, Cultura y Deporte.

[22] Etzkowitz, H., 1998. The norms of entrepreneurial science: cognitive effects of the new university-industry linkages. Research Policy 27: 823-833.

[23] Etzkowitz, H., L. Leydesdorff, 2000. The dynamics of innovation: From National Systems and "Mode 2" to a Triple Helix of academic-industry-government relations. Research Policy 26: 109-123.

[24] Feller, I., 1990. Universities as engines of R\&D-based economic growth: They think they can. Research Policy 19: 335-348.

[25] Fernández de Córdoba, S., 1996. Derecho de patentes e investigación científica. Valencia: Tirant Lo Blanch.

[26] Foltz, J., B. Barham, K. Kim, 2000. Universities and Agricultural Biotechnology Patent Production. Agribusiness 16 (1), 82-95.

[27] Foltz, J., K. Kim, B. Barham, 2001. A Dynamic Count Data Analysis of University AgBiotech Patents. Food Marketing Policy Center Research Report 56.

[28] Geuna, A., 1999. The Economics of Knowledge Production. Cheltenham and Northampton: Edward Elgar.

[29] Greene, W. H., 1994. Accounting for Excess Zeros and Sample Selection in Poisson and Negative Binomial Regression Models. Working paper EC-94-10, Stern School of Business, NYU.

[30] Griliches, Z., 1979. Issues in assessing the contribution of research and development to productivity growth. Bell Journal of Economics 10: 92-116.

[31] Henderson, R., Jaffe, A. B., Trajtenberg, M., 1998. Universities as a source of commercial technology: A detailed analysis of University Patenting, 1965-1988. Review of Economics and Statistics 80 (1): 119-27.

[32] Meyer, M., 2004. Measuring Science-Technology Interaction in the Knowledge-Driven Economy. Book of Abstracts of the 8th International Conference on Science and Technology Indicators, Leiden 23-25 September 2004.

[33] Meyer, M., 2005. Inventor-Authors: Knowledge Integrators or Weak Links?, Institute of Strategy and International Business Working Paper 2005/1. 
[34] Meyer-Krahmer, F., U. Schmoch, 1998. Science-based technologies: universityindustry interactions in four fields. Research Policy 27: 835-51.

[35] Mowery, D. C., B. N. Sampat, 2001. University Patents and Patent Policy Debates in the USA, 1925-1980. Industrial and Corporate Change 10 (3): 781-814.

[36] Mowery, D. C., A. A. Ziedonis, 2002. Academic patent quality before and after the Bayh-Dole act in the United States. Research Policy 31: 399-418.

[37] OECD, 2002. Main Science and Technology Indicators. Paris: Organisation for Economic Cooperation and Development.

[38] Okubo, Y., 1997. Bibliometric indicators and analysis of research systems: Methods and examples. OECD: STI Working Papers 1997/1.

[39] Pavitt, K., 1984. Sectoral patterns of technical change: Towards a taxonomy and a theory. Research Policy 13: 343-373.

[40] Pavitt, K., 1998. Do patents reflect the useful research output of universities? Research evaluation 7 (2): 105-11.

[41] Payne, A. A., A. Siow, 2003. Does Federal Research Funding Increase University Research Output? Advances in Economic Analysis \& Policy 3 (1), Article 1.

[42] Rodríguez-San Pedro, L. E., 2004. Las Universidades hispanas en su contexto histórico.

http://www.universia.es/contenidos/universidades/historia/Universidades historia.htm.

[43] Siegel, D., Waldman, D., Link, A., 2003. Assessing the impact of organizational practices on the productivity of university technology transfer offices: an exploratory study. Research Policy 32: 27-48.

[44] Stephan, P., 1996. The Economics of Science. Journal of Economic Literature 34 (3), 1199-1235.

[45] Thursby, J. G., Kemp, S., 2002. Growth and productive efficiency of university intellectual property licensing. Research Policy 31: 109-124.

[46] Vuong, Q. H., 1989. Likelihood ratio tests for model selection and non-nested hypotheses. Econometrica 57: 307-333.

[47] Xie, Y., K. A. Shauman, 1998. Sex differences in research productivity revisited: new evidence about an old puzzle. American Sociological Review 63, 847-70.

\section{Acknowledgements}

We would have never done this research without support from Ignacio Fernández-de-Lucio and Antonio Gutiérrez-Gracia. Elena Castro-Martínez provided substantial help to find data from the CSIC. We are obliged to them. 
Azagra et al. / X International Congress on Project Engineering

\section{Correspondence}

Joaquín M. Azagra-Caro

INGENIO (CSIC-UPV)

Universidad Politécnica de Valencia, Camino de Vera s/n, 46071 Valencia, Spain

Tel: +34 963877 048; fax: +34 963877091 .

E-mail address: jazagra@ingenio.upv.es 